\title{
Economic impact of leading prosperity diseases: COPD in South East Europe
}

\section{Vojislav Cupurdija ${ }^{1,2}$ *}

${ }^{1}$ Faculty of Medical Sciences, University in Kragujevac, Kragujevac, Serbia

${ }^{2}$ Clinical Center Kragujevac, Clinic for Pulmonary Diseases, Kragujevac, Serbia

${ }^{*}$ Correspondence: vojacup@gmail.com

\section{Edited by:}

Kyriakos Souliotis, University of Peloponnese, Greece

Reviewed by:

Kyriakos Souliotis, University of Peloponnese, Greece

Nick Verhaeghe, Ghent University, Belgium

Keywords: COPD, community acquired pneumonia, cost, resource use, South Eastern Europe

\section{ECONOMIC BURDEN OF COPD}

Chronic obstructive pulmonary disease is one of the leading "prosperity diseases" worldwide. Pooled global prevalence rates based on clinical assessments and spirometry ranged from 7.6 to $8.9 \%$, reported in a sound meta-analytical study design (1). It has far reaching consequences, not only for an affected patient's health but also for the entire national health systems (2). These refer to the substantial work load for the medical facilities due to chronic clinical course of illness and modest success of available treatment approaches. COPD attributable resource utilization patterns are particularly substantial if large university tertiary care hospitals, specialist clinics, and intensive care units are observed (3). According to most of published evidence the key cost driver are periodic exacerbations followed by intensive care unit admissions and episodes of infectious complications (4). Among major cost domains, physician consultations and surgery dominate in high-income settings. Unlike in the West, within the most of South Eastern European region, COPD medical care is still dominated with acquisition costs of pharmaceuticals and oxygen (5) and imaging diagnostics (6). Outpacing of indirect productivity-related opportunity costs by the direct costs of in- and outpatient medical care is common to this region due to substantially lower wages of physicians and nursing staff (7). Apart from direct costs of COPD, mainly constituted from the resources consumed in the health care process, including costs of ambulatory care, drug treatment, hospital care, rehabilitation, and long-term home care, there are substantial indirect costs of COPD, which are incurred by productivity losses, premature retirement, and premature mortality from this disease. The indirect costs for premature mortality are being calculated through human capital approach, with the life years lost up to the age of 65 multiplied by the gross annual income. An insight into the economic reality of SEE region, particularly Serbia, with average wages significantly lower than in countries of the Western Europe, but at the same time with high unemployment rates in younger age groups, where some $50 \%$ of the working population is currently outside of the workforce (8), being in their most productive decades of life but at the same time most prevalent tobacco users, makes indirect cost of COPD in SEE region very difficult to calculate or even predict, but clearly shows significant magnitude of this burden in present years, and probable rise of these costs in the future. Intangible costs are not convertible into monetary terms and units, they are specifically related to the distress and suffering, which is caused by the disease. General lack of insight into patients' perception of the disease and limitation and incapability, which it imposes, while healthcare workers are being focused mainly on physical burden of the disease, with very few patients being provided with structurised psychosocial aid in the attempt to overcome significant yet underestimated mental and emotional burden of the disease, makes these costs impossible to predict and foresee.

\section{AN EXAMPLE OF SERBIA'S HEALTH REFORMS}

Serbia as the largest Western Balkans upper-middle income market began health reforms one decade later than most transitional countries of SEE region $(9,10)$. After dynamic 2000-2007 GDP increase and overall development, the issue of longterm sustainability of its health system financing became hot topic under the first strike of global recession (11). Large part of almost unbearable economic burden was attributable to the major prosperity diseases including pulmonary diseases (12). The unique common weakness revealed by all of these pioneering cost-of-illness assessments in the Balkans region was poor health system responsiveness to population needs together with overextended hospital budgets and accumulating of public depth generated by the national health insurance fund (13). An occurrence of catastrophic household expenditure triggered by severe illness, sinking entire families into poverty is still prevalent within the society (14). Expensive medical technologies, which were denied reimbursement, remained mostly unaffordable to the ordinary citizens (15).

\section{CONSEQUENCES OF COPD RELATIVE TO POPULATION AGING AND COMORBID DISORDERS}

Populations across Eastern Europe and the Balkans are aging even more rapidly than their Western European counterparts. This population aging is likely to further constrain already limited resource allocation in health care (16). This happens mostly due to dwindling base of employed tax payers in their most productive life time combined with increased proportion of the elderly. Demand for medical services by the retired citizens is significantly higher compared to working, younger age groups 
and this is particularly the case within the last year of life (17). Substantial impact of age to the COPD costs of care was already claimed in literature. Clinical severity of disease according to the Global initiative for chronic Obstructive Lung Disease (GOLD) classification, clearly correlated with resource use and costs of hospital and outpatient care (18).

In an exploration of long-term pharmaceutical market transformation trends in Western Balkans, it has been observed that agents used to treat COPD exhibited prominent rise in market share during the past decade. Reported value based turnover of medicines intended to treat respiratory disorders grew from $€ 17,090,000$ in 2004 to the $€ 46,500,000$ in 2012 (19). It is a paradox that during same 9 years unit drug consumption in terms of defined daily doses DDD/1000 inhabitants/day actually fell from 164.55 in 2004 to 50.55 level in 2012 [according to Anatomical Therapeutic Chemical (ATC) classification ("R" ground code group)] (20). Explanation for this shift in Balkan pharmaceutical markets should be looked within stronger brand penetration and modest success of generic pharmaceuticals in many therapeutic areas (21). COPD-related prescription and dispensing of $\beta$-adrenergic preparations in combination with inhalatory corticosteroids ("R03AK" ATC code group) were reported record breaking fivefold increase from $€ 2,682,320$ in 2004 toward $€ 11,761,775$ in 2012 based on latest official release by the National Medicines and Medicinal Device Agency of Serbia (22). Recent dissertation conducted on health economics of community acquired pneumonia (CAP), proved clear proof of substantial COPD comorbidity impact to the overall costs of medical care. While ordinary CAP clinical cases incurred on average $€ 717$ costs in a 1 month time horizon while the ones suffering from COPD and CAP incurred $€ 970$ monthly costs of inpatient care (23).

\section{PROPOSED MEASURES TO TACKLE THE CHALLENGES LYING AHEAD}

Although COPD prevalence and incidence seem to be steadily slowing down in some parts of the European region, this might not be the case with mortality rates. Unfortunately, COPD will most likely be the third leading cause of death worldwide and the fifth leading cause of years lost through early mortality or handicap (disability-adjusted life years) in 2020, which is far worse landscape compared to 1990 (24). So far serious policy initiatives to combat decreased longevity and quality of life caused by COPD have been taken both by WHO and the European COPD Coalition (ECC) (25). Orchestrated supranational efforts to increase research investment in the therapeutic options for COPD were proposed within the Horizon 2020 framework as well (26).

Broad forecasts on COPD for the South Eastern European region may be significantly less optimistic compared to the traditional EU15 economies (see Table 1). Some underlying reasons are strong popular affection toward smoking tobacco among adolescents $(27,28)$ and inefficiencies of anti-tobacco public health campaigns and policies (29). Environmental pollution plays less significant role due to shutting down of most heavy industries in former socialist countries (30) due to socioeconomic transition as well as their lack of global competitiveness (31). Popular opinion on tobacco is gradually beginning to change but this is likely to be a lengthy process. Additional obstacles to this tobacco reduction process seem to be traditionally high prevalence of tobacco smoking habit in Balkan countries such as Bulgaria (32) and FYR Macedonia (33) and heavy investment of global multinational tobacco manufacturers in Serbia and Turkey in particular (34). Essential revenues provided to the local governments by taxation of tobacco sales both to the industry and the consumers is still too important to the regional economies, still outside EU, such as Western Balkans and Turkey. This fact makes tobacco control policies currently in place less successful. Opposingly, promising trend of decreasing tobacco consumption is clearly visible in the OECD economies such as Greece (35), Slovenia, Hungary, and Cyprus where smoking free legislation, higher taxes on cigarettes, and facilitated access to medicines used to treat nicotine addiction are being applied for a number of years in line with the EU health priority targets (36). According to combined tobacco control score (TCS), most countries of South Eastern European region obtained $<50$ grades with the exceptions of Ukraine and Turkey. Interestingly, unsatisfactory and weak tobacco control policies remain in place in a number of traditional high-income European economies.

Containing epidemiological burden of COPD in the Balkans, while providing equitable and affordable medical care for patients will demand surmounting efforts from local communities. Economic consequences in terms of illness attributed lost productivity are huge and due to ongoing upward economic developments in the area likely to increase further. Current national capacities in SEE health care provision remain insufficient, not only in terms of professional staff but also in terms of specialized clinics and rehabilitation facilities, which are still scarce across the region (37). Through the course of past decades, historical network of facilities created to combat tuberculosis was seriously downsized due to successes of innovative vaccines and antibiotics. Another important issue is strong concentration of clinical physicians and nurses in urban cores, leaving rural areas underserved (38).

Far reaching potentially successful strategy to combat COPD in South Eastern Europe would have several distinct features. Such effort should be supranational and should contain key priorities defined within common EU policy on COPD (39). It would have to include peculiarities of local public health and clinical settings, which were already proven to affect resource use and outcomes of COPD medical care (40). Major measures assume prevention of smoking among youth and controlling environmental pollution primarily in large cities. Timely detection of illness by broadly targeted diagnostic screenings could allow more efficient treatment and preserving clinical evolution in its early stages. Evidence based allocation, favoring implementation of cost-effective diagnostic and treatment protocols would help to contain cost without significant adverse influence to the quality of care. Such a complex approach could allow larger portion of local communities to be taken care for, particularly among the poor and underserved citizens.

Although the quantification of the direct health care costs of COPD as well as indirect and intangible costs in these 


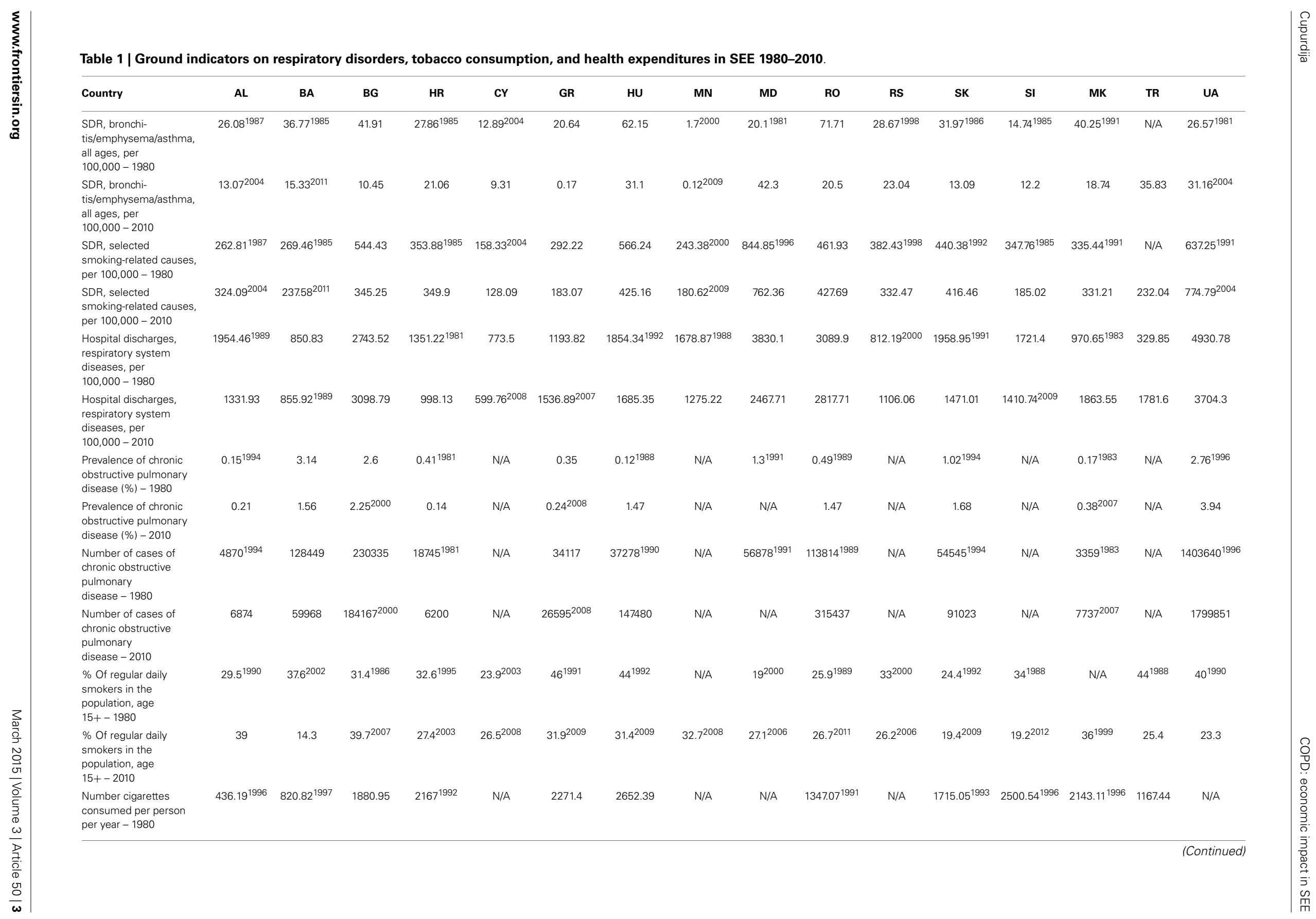


Table 1 | Continued

\begin{tabular}{|c|c|c|c|c|c|c|c|c|c|c|c|c|c|c|c|c|}
\hline Country & AL & BA & BG & HR & CY & GR & HU & MN & MD & RO & RS & SK & SI & MK & TR & UA \\
\hline $\begin{array}{l}\text { Number cigarettes } \\
\text { consumed per person } \\
\text { per year }-2010\end{array}$ & $744.06^{2000}$ & $1244.01^{2000}$ & $2792.6^{2000}$ & $1736.68^{2000}$ & N/A & $3200.49^{2004}$ & $2151.41^{2000}$ & N/A & N/A & $1392.63^{1997}$ & N/A & $1230.4^{2000}$ & $2232.86^{2000}$ & $1794.36^{2000}$ & $1547.84^{1998}$ & $1027^{2000}$ \\
\hline $\begin{array}{l}\text { Sulfur dioxide emissions, } \\
\text { kg per capita per } \\
\text { year - } 1980\end{array}$ & N/A & $107.19^{1990}$ & 231.34 & 32.72 & N/A & 41.48 & 152.46 & N/A & 76.78 & 47.52 & N/A & 156.49 & 123.41 & N/A & 4.59 & 77.14 \\
\hline $\begin{array}{l}\text { Sulfur dioxide emissions, } \\
\text { kg per capita per } \\
\text { year }-2010\end{array}$ & N/A & N/A & $104.77^{2000}$ & $15.98^{2000}$ & $\mathrm{~N} / \mathrm{A}$ & $50.01^{2000}$ & $53.86^{2000}$ & N/A & $31.61^{2000}$ & $40.12^{1994}$ & N/A & $38.88^{2000}$ & $13.57^{2000}$ & $52.3^{1998}$ & $15.49^{2000}$ & $46.91^{2000}$ \\
\hline $\begin{array}{l}\text { Average annual } \\
\text { concentration of sulfur } \\
\text { dioxide }\left(\mathrm{SO}_{2}\right) \text { in capital, } \\
\mu \mathrm{g} / \mathrm{m}^{3}-1980\end{array}$ & N/A & $18.4^{2002}$ & $27.4^{1998}$ & N/A & $\mathrm{N} / \mathrm{A}$ & $22.2^{1997}$ & $41.6^{1997}$ & N/A & N/A & N/A & $58.6^{2003}$ & $25.4^{1997}$ & $35.4^{1997}$ & $27.3^{1997}$ & N/A & N/A \\
\hline $\begin{array}{l}\text { Average annual } \\
\text { concentration of sulfur } \\
\text { dioxide }\left(\mathrm{SO}_{2}\right) \text { in capital, } \\
\mu \mathrm{g} / \mathrm{m}^{3}-2010\end{array}$ & $38.5^{2009}$ & 35.1 & 9.4 & N/A & N/A & $5.7^{2008}$ & 6.7 & N/A & N/A & 15 & 37.8 & 19.5 & $2^{2008}$ & 1.3 & 12.6 & N/A \\
\hline $\begin{array}{l}\text { Average annual } \\
\text { concentration of } \\
\text { particulate matter } \\
<10 \mu \mathrm{m}(\mathrm{PM} 10) \text { in the } \\
\text { capital, } \mu \mathrm{g} / \mathrm{m}^{3}-1980\end{array}$ & N/A & N/A & $20.4^{2000}$ & N/A & N/A & $34.7^{2001}$ & $35^{2003}$ & N/A & N/A & N/A & $52.7^{2004}$ & $36.5^{1999}$ & $30.9^{2002}$ & N/A & N/A & N/A \\
\hline $\begin{array}{l}\text { Average annual } \\
\text { concentration of } \\
\text { particulate matter } \\
<10 \mu \mathrm{m}(\mathrm{PM} 10) \text { in the } \\
\text { capital, } \mu \mathrm{g} / \mathrm{m}^{3}-2010\end{array}$ & $22.6^{2009}$ & 48.5 & 48.4 & N/A & N/A & $30.4^{2007}$ & 31.9 & N/A & N/A & 35.4 & 23.1 & 26.6 & $29.4^{2009}$ & N/A & 59.5 & N/A \\
\hline $\begin{array}{l}\text { Average annual } \\
\text { concentration of nitrogen } \\
\text { dioxide }\left(\mathrm{NO}_{2}\right) \text { in capital, } \\
\mu \mathrm{g} / \mathrm{m}^{3}-1980\end{array}$ & N/A & $27^{2002}$ & $39.7^{2003}$ & N/A & N/A & $50.8^{1997}$ & $53.2^{1997}$ & N/A & N/A & N/A & $40.2^{2003}$ & $34.3^{1997}$ & $31.6^{2002}$ & N/A & N/A & N/A \\
\hline $\begin{array}{l}\text { Average annual } \\
\text { concentration of nitrogen } \\
\text { dioxide }\left(\mathrm{NO}_{2}\right) \text { in capital, } \\
\mu \mathrm{g} / \mathrm{m}^{3}-2010\end{array}$ & N/A & 25.7 & 31.3 & N/A & N/A & $42.4^{2008}$ & 28.1 & N/A & N/A & $20.5^{2011}$ & 27.9 & 13.3 & 34.7 & $15^{2009}$ & N/A & N/A \\
\hline $\begin{array}{l}\text { Average annual } \\
\text { concentration of ozone } \\
\left(\mathrm{O}_{3}\right) \text { in the capital, } \\
\mu \mathrm{g} / \mathrm{m}^{3}-1980\end{array}$ & N/A & $68.4^{2006}$ & $4.4^{1999}$ & N/A & N/A & $75.8^{1997}$ & $69^{1997}$ & N/A & N/A & N/A & $65.4^{2004}$ & $72^{1998}$ & $66^{1998}$ & N/A & N/A & $\mathrm{N} / \mathrm{A}$ \\
\hline $\begin{array}{l}\text { Average annual } \\
\text { concentration of ozone } \\
\left(\mathrm{O}_{3}\right) \text { in the capital, } \\
\mu \mathrm{g} / \mathrm{m}^{3}-2010\end{array}$ & N/A & 53.6 & 65.4 & N/A & N/A & $88.6^{2008}$ & $73.7^{2009}$ & N/A & $\mathrm{N} / \mathrm{A}$ & 57.7 & $71.2^{2011}$ & 71.6 & 63.7 & N/A & N/A & N/A \\
\hline $\begin{array}{l}\text { Total health expenditure, } \\
\text { PPP\$ per capita, WHO } \\
\text { estimates - } 1980\end{array}$ & $97.6^{1995}$ & $128.44^{1955}$ & $290.22^{1995}$ & $546.04^{1995}$ & $722.76^{1995}$ & $1263.1^{1995}$ & $656.74^{1995}$ & $445.18^{1995}$ & $115.12^{1995}$ & $183.44^{1995}$ & $259.86^{1995}$ & $503.8^{1995}$ & $969.4^{1995}$ & $421.4^{1995}$ & $174.12^{1995}$ & $246.56^{1995}$ \\
\hline $\begin{array}{l}\text { Total health expenditure, } \\
\text { PPP\$ per capita, WHO } \\
\text { estimates - } 2010\end{array}$ & 481.9 & 833.74 & 1053.1 & 1461.7 & 2221.68 & 2584.6 & 1653.88 & 947.86 & 369.66 & 880.94 & 1183.44 & 2088.18 & 2366.4 & 772.02 & 1071.54 & 520.44 \\
\hline
\end{tabular}


countries is very difficult, it is clear that pulmonary specialists across the South Eastern Europe region are challenged to increase their efforts to reduce the menace of smoking and to put in additional efforts in creation of new strategies aimed at early diagnostics. The estimation of total health care costs can therefore only be a first step in assessing the overall impact of COPD burden in South East Europe region. Further studies on the economic burden of COPD, including the perspective of mostly underestimated indirect and intangible costs within the region will be needed to prove and justify the prevention and early diagnostics efforts and development of new strategies of reduction of both financial and non-financial burden of disease. Many policy makers are starting to realize that a more robust evidence base is needed in order to make informed decisions on resource allocation. In light of current weaknesses of regional health financing, funding the quest for knowledge of the local cost drivers of key clinical conditions represents a valuable investment in the future of emerging markets (41).

COPD with its multimillion patient population in the SEE region should be regarded as one of the high-profile policy issues on the agenda of national health ministries and governmental agencies. Future of these patients remains particularly unpredictable among the small Western Balkan economies approaching EU membership.

\section{ACKNOWLEDGMENTS}

The Ministry of Education Science and Technological Development of the Republic of Serbia has funded this study through Grant OI 175014. Publication of results was not contingent to Ministry's censorship or approval.

\section{REFERENCES}

1. Halbert RJ, Natoli JL, Gano A, Badamgarav E, Buist AS, Mannino DM. Global burden of COPD: systematic review and meta-analysis. Eur Respir $J$ (2006) 28(3):523-32. doi:10.1183/09031936.06. 00124605

2. Mannino DM, Buist AS. Global burden of COPD: risk factors, prevalence, and future trends. Lancet (2007) 370(9589):765-73. doi:10.1016/ S0140-6736(07)61380-4

3. Oostenbrink JB, Rutten-van Mölken MP. Resource use and risk factors in high-cost exacerbations of
COPD. Respir Med (2004) 98(9):883-91. doi:10. 1016/j.rmed.2004.02.013

4. Andersson F, Borg S, Jansson SA, Jonsson AC, Ericsson A, Prütz C, et al. The costs of exacerbations in chronic obstructive pulmonary disease (COPD). Respir Med (2002) 96(9):700-8. doi:10.1053/rmed. 2002.1334

5. Cizman M, Beovic B, Krcmery V, Barsic B, Tamm E, Ludwig E, et al. Antibiotic policies in Central Eastern Europe. Int $J$ Antimicrob Agents (2004) 24(3):199-204. doi:10.1016/j.ijantimicag. 2004.03.016

6. Ranković A, Rančić N, Jovanović M, Ivanović M, Gajović O, Lazić Z, et al. Impact of imaging diagnostics on the budget-are we spending too much? Vojnosanit Pregl (2013) 70(7):709-11.

7. Bernaciak M, Duman A, Šćepanović V. Employee welfare and restructuring in the public sector: evidence from Poland and Serbia. Eur $J$ Ind Relat (2011) 17(4):365-80. doi:10.1177/ 0959680111420697

8. Available from: www.worldbank.org

9. Simić S, Milićević MS, Matejić B, Marinković J, Adams O. Do we have primary health care reform? The story of the Republic of Serbia. Health Policy (2010) 96(2):160-9. doi:10.1016/j.healthpol.2010. 01.015

10. Bjegovic V, Vukovic D, Terzic Z, Milicevic MS, Laaser UT. Strategic orientation of public health in transition: an overview of South Eastern Europe. J Public Health Policy (2007) 28(1):94-101. doi:10. 1057/palgrave.jphp.3200121

11. Jakovljević M, Jovanović M, Lazić Z, Jakovljevic V, Djukic A, Velickovic R, et al. Current efforts and proposals to reduce healthcare costs in Serbia. Ser J Exp Clin Res (2011) 12(4):161-3. doi:10.5937/ sjecr1104161J

12. Jakovljevic M, Cupurdija V, Lazic Z. Cost of illness of community-acquired pneumonia. Review of the literature and possible strategies in the Serbian health care setting. SEEd Medical Publishers, Farmeconomia. Health Econ Therap Pathw (2013) 14(4):133-9.

13. Jakovljevic MB. Resource allocation strategies in Southeastern European health policy. Eur J Health Econ (2013) 14(2):153-9. doi:10.1007/s10198012-0439-y

14. Arsenijevic J, Pavlova M, Groot W. Out-of-pocket payments for public healthcare services by selected exempted groups in Serbia during the period of post-war healthcare reforms. Int J Health Plann Manage (2014) 29:373-98. doi:10.1002/hpm.2188

15. Jakovljevic MB. Oncology monoclonal antibodies expenditure trends and reimbursement projections in the emerging Balkan market. SEEd Medical Publishers, Farmeconomia. Health Econ Therap Pathw (2014) 15(1):27-32.

16. Ogura S, Jakovljevic M. Health financing constrained by population aging - an opportunity to learn from Japanese experience. Ser J Exp Clin Res (2014) 15(4):175-81. doi:10.2478/SJECR2014-0022

17. Kovacevic A, Dragojevic-Simic V, Rancic N, Jurisevic M, Gutzwiller F, Matter-Walstra $K$, et al. Endof-life costs of medical care for advanced stage cancer patients. Vojnosanit Pregl (2015) 72(4). (in press).

18. Lazic Z, Gajovıc O, Tanaskovic I, Milovanovic D, Atanasijevic D, Jakovljevic M. GOLD stage impact on COPD direct medical costs in elderly. J Health Behav Public Health (2012) 2(3):1-7.

19. Jakovljevic M, Djordjevic N, Jurisevic M, Jankovic S. Evolution of Serbian pharmaceutical market alongside socioeconomic transition. Expert Rev Pharmacoecon Outcomes Res (2015). doi:10.1586/ 14737167.2015.1003044

20. WHO. Anatomical Therapeutic Chemical (ATC) classification system. Available from: http://www. whocc.no/atc_ddd_index/

21. Jakovljevic MB, Nakazono S, Ogura S. Contemporary generic market in Japan - key conditions to successful evolution. Expert Rev Pharmacoecon Outcomes Res (2014) 14(2):181-94. doi:10.1586/ 14737167.2014 .881254

22. Medicines and Medical Devices Agency of Serbia. Available from: http://www.alims.gov.rs/ciril/ o-agenciji/publikacije/ppl2012/

23. Cupurdija V. Cost Drivers of Community Acquired Pneumonia Treatment. University of Kragujevac: Serbia (2014). Doctoral Dissertation.

24. Raherison C, Girodet PO. Epidemiology of COPD. Eur Respir Rev (2009) 18(114):213-21. doi:10. 1183/09059180.00003609

25. The European COPD Coalition. Available from: http://www.copdcoalition.eu/what_we_do/ copd-in-the-european-union-political-agenda/ copd-to-be-part-of-eu-medicine-research-priority

26. Available from: http://www.copdcoalition.eu/ news/conference-report-copd-and-horizon-2020

27. Karekla M, Symeou A, Tsangari H, Kapsou M, Constantinou M. Smoking prevalence and tobacco exposure among adolescents in Cyprus. Eur J Public Health (2009) 19(6):655-61. doi:10.1093/ eurpub/ckp064

28. Shterev F, Mateva N, Ivancheva R, Belev G, Kartev S, Yankova Z. Inquiry of tobacco smoking among students in Plovdiv. Med Preg/Med Rev (2007) 43(3):85-9.

29. Lovato C, Linn G, Stead LF, Best A. Impact of tobacco advertising and promotion on increasing adolescent smoking behaviours. Cochrane Database Syst Rev (2003) (4):CD003439. doi:10.1002/ 14651858.CD003439

30. Lausevic R, Popovic A. Setting up an integrated industrial emissions reporting tool: a case study from Serbia. S East Eur Environ Outlook (2013) 63-74.

31. Bandelj N. The rise of management education in post-socialism. In: Schuerkens U, editor, Global Management, Local Resistances: Theoretical Discussion and Empirical Case Studies. New York: Routledge (2014). p. 35-52.

32. Kavalski E. Balkan smoke: tobacco and the making of modern Bulgaria. Eur Asia Stud (2014) 66(7):1194-5. doi:10.1080/09668136.2014. 934137

33. Arsov Z, Kabranova R, Dimov Z, Spirkovska M. Analysis of production and purchase of oriental tobacco in Balkan. International Symposium for Agriculture and Food, XXXVII Faculty - Economy Meeting, IV Macedonian Symposium for Viticulture and Wine Production, VII Symposium for Vegetables and Flower Production. Skopje (2012). p. 9-19.

34. Onder Z. The Economics of tobacco in Turkey: new evidence and demand estimates. Economics of Tobacco Control, Paper No 2,2002. The International Bank for Reconstruction and Development / The 
World Bank. Washington: US Centers for Disease Control/Office on Smoking and Health (2002).

35. Vardavas CI, Kafatos AG. Smoking policy and prevalence in Greece: an overview. Eur J Public Health (2007) 17(2):211-3. doi:10.1093/eurpub/ ckl094

36. Joossens L, Raw M. The Tobacco Control Scale 2013 in Europe. Available from: http://www.euro peancancerleagues.org/images/TobaccoControl/ TCS_2013_in_Europe_13-03-14_final_1.pdf

37. Ognyanova D, Busse R. Health workforce mobility and policy responses in South East Europe. In: Bartlett W, Bozikov J, Rechel B, editors. Health Reforms in South-East Europe. Houndsmills: Palgrave Macmillan (2012). p. 76-101.

38. Yikilkan H, Gorpelioglu S, Aypak C, Uysal Z, Ariman OO. Differences between rural and urban primary care units in Turkey: implications on residents' training. J Family Med Prim Care (2013) 2(1):15-9. doi:10.4103/2249-4863.109935
39. Lessons to Address the Poor State of COPD Care in Europe and Research in Horizon 2020. Available from: http://www.copdcoalition.eu/what_ we_do/world-copd-day/lessons-to-address-thepoor-state-of-copd-care-in-europe-and-researchin-horizon-2020

40. Jakovljevic M, Lazic Z, Verhaeghe N, Jankovic S, Gajovic O, Annemans L. Direct medical costs of COPD diagnosis and treatment, Eastern vs. Western European country - examples of Serbia and Belgium. Health Econ Therap Pathw (2013) 14(4):161-8.

41. Jakovljevic MB. The key role of leading emerging BRIC markets for the future of global health care. Ser J Exp Clin Res (2014) 15(3):139-43. doi:10.5937/sjecr1403139J

Conflict of Interest Statement: The author declares that the research was conducted in the absence of any commercial or financial relationships that could be construed as a potential conflict of interest.

Received: 28 January 2015; accepted: 07 March 2015; published online: 24 March 2015.

Citation: Cupurdija V (2015) Economic impact of leading prosperity diseases: COPD in South East Europe. Front. Public Health 3:50. doi: 10.3389/fpubh.2015.00050

This article was submitted to Epidemiology, a section of the journal Frontiers in Public Health.

Copyright $(2015$ Cupurdija. This is an open-access article distributed under the terms of the Creative Commons Attribution License (CC BY). The use, distribution or reproduction in other forums is permitted, provided the original author(s) or licensor are credited and that the original publication in this journal is cited, in accordance with accepted academic practice. No use, distribution or reproduction is permitted which does not comply with these terms. 